УДК 378

DOI https://doi.org/10.26661/2522-4360-2021-2-35

\title{
КОУЧИНГОВИЙ ПІДХІД ЯК ЕФЕКТИВНИЙ ІНСТРУМЕНТ РОЗВИТКУ ІНШОМОВНОЇ КОМПЕТЕНТНОСТІ ЗДОБУВАЧІВ ОСВІТИ ВИЩИХ НАВЧАЛЬНИХ ЗАКЛАДІВ
}

\author{
Дідківська Ю. А. \\ викладач кафедри іноземної філології та перекладу \\ Київський національний торговельно-економічний університет \\ вул. Кіото, 19, Київ, Україна \\ orcid.org/0000-0002-6346-7105 \\ i.didkivsk@knute.edu.ua
}

Ключові слова: коучинг, іншомовна компетентність, вища освіта, здобувачі освіти економічних спеціальностей, стратегія вивчення іноземної мови, індивідуальна освітня траєкторія.
У статті узагальнено досвід викладання англійської мови з використанням коучингового підходу для здобувачів освіти економічних спеціальностей Київського національного торговельно-економічного університету. Коучингові технології є дієвим інструментом осучаснення навчального процесу, переходу до студентоцентрованого навчання, налагодження партнерських відносин між учасниками освітнього процесу, розкриття особистого інтелектуального й емоційного потенціалу здобувачів освіти. Актуальність дослідження пов'язана з тим, що використання коучингових технологій у процесі вивчення іноземних мов лише набуває популярності в Україні і тому потребує наукового осмислення. Мета дослідження полягає у аналізі практичних занять з іноземної мови з використанням коучингових технологій. Мета реалізується у таких завданнях: 1) надати характеристику видів навчальної діяльності на практичних заняттях 3 іноземної мови 3 використанням коучингових технологій; 2) проаналізувати їхню ефективність у аспекті підвищення мотивації студентів до навчання, формування іншомовної компетентності та набуття soft skills. У статті охарактеризовано такі види навчальної активності, як побудова власної стратегії і тактики навчання, колективний перегляд i обговорення мотиваційних відеоматеріалів, а також робота у мікрогрупі, один із членів якої виконує роль коуча. Доведено, що використання коучингового підходу у процесі навчання іноземної мови дає змогу створити атмосферу взаємодії, під час якої здобувачі освіти набувають іншомовної компетентності шляхом проходження власної освітньої траєкторії, а викладач виступає в ролі супервайзера, який допомагає рекомендацією та порадою. Важливим результатом упровадження коучингового підходу також є полегшення для викладача організації навчального процесу і контролю програмних результатів навчання. 


\title{
COACHING APPROACH AS AN EFFECTIVE TOOL FOR DEVELOPING FOREIGN LANGUAGE COMPETENCE OF HIGHER EDUCATION APPLICANTS
}

\author{
Didkivska Yu. A. \\ Lecturer at the Department of Foreign Philology and Translation \\ Kyiv National University of Trade and Economics, \\ Kioto str., 19, Kyiv, Ukraine \\ orcid.org/0000-0002-6346-7105 \\ i.didkivsk@knute.edu.ua
}

Key words: coaching, foreign language competence, higher education, students of economic specialties, foreign language learning strategy, individual educational trajectory.
The article summarizes the experience of teaching English using a coaching approach for students of economic specialties of the Kyiv National University of Trade and Economics. Coaching technologies are an effective tool for modernizing the educational process, the transition to student-centered learning, establishing partnerships between participants in the educational process, the disclosure of personal intellectual and emotional potential of students. The relevance of the study is due to the fact that the use of coaching technologies in the process of learning foreign languages is only gaining popularity in Ukraine and therefore requires scientific understanding. The purpose of the study is to analyze practical classes in a foreign language using coaching technologies. The purpose is realized in the following tasks: 1) to give the characteristic of kinds of educational activity at practical lessons on a foreign language with use of coaching technologies; 2) to analyze their effectiveness in terms of increasing student motivation to learn, the formation of foreign language competence and the acquisition of soft skills. The article describes such types of learning activities as building individual learning strategy and tactics, collective viewing and discussion of motivational videos, as well as work in a microgroup, one of the members of which acts as a coach. It is proved that the use of a coaching approach in the process of learning a foreign language allows create an atmosphere of interaction, during which students acquire foreign language competence by passing their own educational trajectory, and the teacher acts as a supervisor who helps with advice. An important result of the implementation of the coaching approach is also the facilitation for the teacher of the organization of the educational process and control of program learning outcomes.
Постановка проблеми. Організація занять 3 іноземної мови 3 використанням коучингового підходу є дієвою формою модернізації освітнього процесу у вищій школі. Це дає змогу подолати комунікативні бар'єри у системі «викладач - здобувач освіти», налагодивши партнерські стосунки. Варто усвідомлювати, що коучингові технології виникли в англомовних країнах, тому для студентів корисним $€$ ознайомлення 3 оригінальними зразками коучингової діяльності. Це водночас підвищує іншомовну компетентність і мотивацію до вивчення іноземної мови.

Аналіз останніх досліджень і публікацій. Коучинговий підхід в освіті, зокрема у вищій, сьогодні знаходиться у центрі уваги зарубіжних i вітчизняних науковців. Так, Г. Поберезька розглядає цей підхід в аспекті студентоцентрованого навчання, визначаючи коучинг як «творчу взаємодію рівноправних учасників освітнього процесу, спрямовану на виявлення та реалізацію потенціалу того, хто навчається, для досягнення ним високого освітньо-професійного, соціального, особистісного розвитку» [1, с. 104]. Дослідниця зазначає, що запитання як основний інструмент коуча сприяють мобілізації та реалізації внутрішнього потенціалу здобувачів освіти [1, с. 105]. І. Олійник вважає коучинг одним із ресурсних аспектів у педагогічній діяльності, що передбачає «трансформацію взаємозв'язків між викладачем-коучем і здобувачами, новий рівень міжособистісної взаємодії на основі педагогіки співробітництва і гнучкості у процесі вирішення проблем» [2, с. 166].

Багатоаспектне осмислення використання коучингових технологій в освіті міститься у праці колективу польських учених [3]. Інтерактивний потенціал коучингу розкривається у розвідці О. Рудницьких [4]. В. Каплінський, Н. Бурлака та В. Фрицюк пропонують ввести до підготовки 
педагогів освітній компонент «Коучинг в освіті» [5], адже «коуч допомагає розкрити внутрішні ресурси здобувача вищої освіти для досягнення позитивних змін в його поведінці та діяльності, стати більш гнучким у контактах, більш творчо підходити до вирішення професійних завдань, відчути радість від можливості спостерігати процес власного внутрішнього зростання як особистості та від зародження і посилення внутрішньої мотивації до діяльності» [5, с. 74]. 3 цією думкою суголосна наукова студія Б. Савчука, Г. Білавич i Ю. Душенко, які вважають, що «особливість і перевага коучингової технології педагогічного супроводу полягають у виразній особистісній, соціальній, професійній орієнтованості на здобувача освіти, який позитивно мотивується та почувається морально врівноваженим, упевненим, захищеним і виявляє готовність до самореалізації свого потенціалу, адекватної самооцінки, подальшого саморозвитку» [6, с. 86].

Ефективність коучингу в аспекті компетентнісного навчання і педагогіки партнерства підкреслюється у працях українських $[7 ; 8 ; 9 ; 10 ; 11 ; 12]$ i польських [13] учених. На думку Л. Кудрик i О. Банах, коучинг допомагає розвинути різні типи мислення: критичне, відповідальне, системне, рефлексивне, позитивне, креативне [10, с. 59]. Дослідники акцентують роль коучингу як інструменту підвищення мотивації до навчальної діяльності $[14 ; 15 ; 16 ; 17 ; 18 ; 19]$.

Основну увагу в аспекті цього дослідження привертають наукові розвідки, присвячені використанню коучингу для формування іншомовної компетентності $[20 ; 21 ; 22]$. Водночас варто констатувати певний брак студій, у яких би було детально подано алгоритм проведення занять 3 іноземної мови для здобувачів вищої освіти 3 використанням коучингових технологій.

Метою статті $\epsilon$ узагальнення досвіду проведення практичних занять 3 іноземної мови з використанням коучингових технологій. Відповідно до мети визначені такі завдання дослідження: 1) надати характеристику видів навчальної діяльності на практичних заняттях з іноземної мови 3 використанням коучингових технологій; 2) проаналізувати їхню ефективність у аспекті підвищення мотивації студентів до навчання, формування іншомовної компетентності та набуття soft skills.

Виклад основного матеріалу. У статті узагальнено досвід проведення практичних заняття 3 іноземної мови 3 використанням коучингових технологій для здобувачів освіти економічних спеціальностей Київського національного торговельно-економічного університету.

Обов'язковим початковим різновидом навчальної діяльності на заняттях 3 іноземної мови 3 використанням коучингового підходу вважаємо побудову студентами власної стратегії і тактики вивчення мови, тобто індивідуальної траєкторії. Здобувачам освіти пропонується чітко визначити конкретну мету вивчення мови (не лише краще знати англійську, а, наприклад, отримати певний сертифікат, який дає змогу навчатися у закордонних університетах; знайти роботу у міжнародній компанії; вільно спілкуватися з іноземцями, читати іншомовну літературу тощо). Потім необхідно визначити термін, необхідний для цього. Терміни мають бути реальними. Після цього здобувач має визначитися 3 найзручнішими і кориснішими саме для нього формами навчальної активності - для деяких це буде робота $з$ традиційними текстами (публіцистичними, художніми, професійними чи науковими) та словниками, хтось обирає перегляд стрічок або слухання музики, для когось головною формою є усне спілкування 3 носіями мови. Ці форми навчання здобувачі ранжують за пріоритетністю. Далі вони будують план-графік вивчення мови - увесь термін розбивається на місяці та тижні i для кожного періоду визначаються конкретні типи і результати навчальної активності. Також здобувач освіти має визначити показники успішності і критерії оцінювання досягнутих результатів. Розбудова власної траєкторії та чітке планування сприяють розкриттю особистого потенціалу кожного учасника освітнього процесу, підвищують мотивацію до навчання завдяки усвідомленню власних цілей $\mathrm{i}$ можливостей. Для викладача значно полегшується організація навчального процесу і контроль програмних результатів навчання, адже він розуміє, які саме завдання і коли ставити перед конкретним здобувачем.

Одним з основних різновидів навчальної діяльності на практичних заняттях 3 іноземної мови вважаємо перегляд оригінальних (англомовних) мотиваційних відеоматеріалів. Візуальний матеріал для сучасних студентів $\epsilon$ найбільш сприйнятливим, адже постміленіали звикли до такого формату подання навчальної інформації. Підбір відеоматеріалів належить до самостійної роботи здобувачів освіти: вони вибирають, що саме буде найцікавішим для спільного перегляду на заняттях. Це можуть бути відео виступів англомовних коучів, анімаційні відеоролики, фрагменти художніх або документальних стрічок тощо. Завдання для здобувачів - знайти такі відеоматеріали, які мотивують до вивчення англійської мови. На занятті переглядається один відеоматеріал. Після перегляду відбувається колективне обговорення відеоматеріалу англійською мовою. Здобувач освіти, відеоматеріал якого обговорюється, грає роль коуча: він ставить решті здобувачів запитання щодо мотивів і цілей вивчення англійської мови, шляхів і засобів навчання тощо. Викладач під час такого різновиду навчальної діяльності 
$\epsilon$ супервайзером процесу та модератором дискуciï. У процесі такої роботи відбувається формування іншомовної компетентності, критичного мислення, рефлексії, усвідомлення важливості оволодіння іноземною мовою. Також формуються такі важливі soft skills, як навички грамотної вербальної та невербальної поведінки, вміння володіти аудиторією, утримувати іï увагу тощо.

Ще одним дієвим різновидом організації практичного заняття з іноземної мови з використанням коучингових технологій $\epsilon$ робота у мікрогрупах. Здобувачі освіти розбиваються на пари або трійки залежно від розміру академічної групи. У мікрогрупі обирається коуч. Він ставить запитання членам своєї команди стосовно прикладного значення теми, яка вивчається на занятті. Наприклад, темою практичного заняття $\epsilon$ складання резюме. Коуч запитує, яку роль відіграє резюме у сучасному діловому світі, якими $є$ критерії успішності резюме, як швидко скласти його тощо. Після оприлюднення результатів роботи усіх мікрогруп обирається найкращий коуч групи. Наприкінці заняття відбувається колективне обговорення. Така навчальна активність розвиває (окрім іншомовної компетентності) лідерські якості, формує навички командної роботи та діалогічного спілкування.

Висновки. Отже, використання такої інноваційної освітньої технології, як коучинг, у процесі навчання іноземної мови дає змогу перетворити традиційний процес навчання на партнерську взаємодію викладача і здобувачів, під час якої останні досягають своєї мети шляхом проходження власної освітньої траєкторії, а викладач виконує роль супервайзера, який допомагає рекомендацією чи дружньою порадою, коригує процес, підтримує i надихає. Перспективу в аспекті подальших досліджень бачимо у розробленні планів конкретних занять 3 іноземної мови з використанням інструментів коучингу, а також в організації педагогічного експерименту з метою аналізу ефективності кожного з різновидів навчальної активності в аспекті розвитку іншомовної компетентності.

\section{ЛIТЕРАТУРА}

1. Поберезська Г.Г. Коучинг як педагогічна технологія студенто-центричного навчання у ВНЗ. Технологія і техніка друкарства. 2017. № 4 (58). С. 99-107.

2. Олійник І.В. Використання коучинг-технології у процесі формування дослідницької компетентності у майбутніх докторів філософії в умовах аспірантури Вісник університету імені Альфреда Нобеля. Педагогічні науки. Серія «Педагогіка і психологія». 2019. № 1 (17). С. 158-167.

3. Cywińska A., Majewska S., Pępiak-Kowalska K., Szwec E. Coaching. Lublin: Wydanie pierwsze, 2013. $190 \mathrm{~s}$.

4. Рудницьких О.В. Коучінг як інтерактивна технологія в освіті. Вісник Дніпропетровського університету імені Альфреда Нобеля. Серія: Педагогіка і психологія. 2014. № 2. С. 173-176.

5. Каплінський В.В., Бурлака Н.І., Фрицюк В.А. Роль навчальної дисципліни «Коучинг в освіті» у підготовці магістрів спеціальності 011 Освітні, педагогічні науки. Наукові записки ВДПУ імені Михайла Коиюбинського. Серія: педагогіка і психологія. 2020. Вип. 64. С. 72-77.

6. Савчук Б., Білавич Г., Душенко Ю. Коучинг як філософія і технологія розвитку професійної педагогічної освіти. Гірська школа Украӥнських Карпат. 2019. № 21. С. 82-87.

7. Горук Н. Коучинг як ефективна технологія формування самоосвітньої компетентності студентів. Проблеми підготовки сучасного вчителя. 2015. № 11. С. 99-105.

8. Шевчук С.П., Шевчук О.С. Коучинг як метод навчання студентів у контексті реформування вищої освіти України. 3б. наук. пращь Чорномор. держ. у-ту ім. П. Могили. Сер.: Педагогіка. 2016. № 269 (257). С. 62-65.

9. Нежинська О.О., Тименко В.М. Основи коучингу: навчальний посібник. Київ; Харків: ТОВ «ДІСА ПЛЮС», 2017. 220 c.

10. Кудрик Л.Г., Банах О.В. Переваги освітнього коучингу в контексті педагогіки партнерства. Шляхи удосконалення професійних компетентностей фахівців в умовах сьогодення: матеріали Міжнар. наук.-практ. інтернет конф. (Київ, 28-29 травня 2020 р.) / уклад.: О.Ю. Дикий, Г.А. Коломоєць, А.А. Ребрина. Луцьк: СНУ ім. Лесі Українки, 2020. С. 58-61.

11. Чернова Т.Ю., Голіяд І.С., Тіщук О.А. Педагогічний коучинг: навч.-метод. посіб. / за заг. ред. Д. Е. Кільдерова. Київ, 2016. 166 с.

12. Самокоучинг: Як запобігти професійному вигоранню / авт.-упоряд. Л. Кудрик, А. Бешлей, У. Мельник. Київ: «Видавнича група «Шкільний світ», 2019. 216 с.

13. Stoltzfus T. Sztuka zadawania pytań w coachingu. Wrocław: Wyd. Aetos Media, 2012. $102 \mathrm{~s}$.

14. Ніколаєв Л., Романенко Н. Підвищення мотивації студентів ВНЗ до навчальної діяльності: коучинговий підхід. Improving living standards: current opportunities and limitations: monograph / ed.: Wojciech Duczmal, Iryna Ostopolets. Opole: The Academy of Management and Administration in Opole, 2020. P. $507-517$. 
15. Кузан Г. Освітній коучинг як інноваційна технологія професійної підготовки фахівців соціальної та соціально-педагогічної сфери у вищій школі. Молодь і ринок. 2019. № 3 (170). С. 81-84.

16. Голіяд І.С., Чернова Т.Ю. Роль коучингової компетентності педагога у розкритті потенціалу суб'єкта освітнього процесу. Науковий часопис Національного педагогічного університету імені М. П. Драгоманова. Серія 13: Проблеми трудової та професійної підготовки: зб. наук. праць. Київ: Вид-во НПУ ім. М. П. Драгоманова, 2017. Вип. 8. С. 20-25.

17. Білик Н.І., Любченко Н.В. Педагогічний коучинг як технологія професійного розвитку вчителя в системі підвищення кваліфікації. Імідж сучасного педагога. 2020. № 5 (194). С. 41-46.

18. Хмельницька С. Коучинг як сучасна технологія підвищення ефективності навчального процесу. Молодий вчений. 2017. № 6. С. 315-319.

19. Costa L.A., Garmston J.R. Cognitive coaching: developing self-directed leaders and learners. 3rd ed. Lanham, MD: Rowman and Littlefield Publishers, 2016. 408 p.

20. Семегин Т.С., Кучер В.В. Використання коучингу під час формування іншомовної комунікативної компетентності студентів. Педагогіка формування творчої особистості у вищій $і$ загальноосвітній школах. 2021. № 75, Т. 3. С. 57-60.

21. Жовнір М.М. Коучинг-технології на заняттях мовного циклу: до питання впровадження і контролю навчальних досягнень студентів. Актуальні питання контролю якості освіти у вищих навчальних закладах: матер. науково-практичної конференції (Полтава, 22 березня 2018 р.). Полтава: ВДНЗУ «УМСА», 2018. С. 91-93.

22. Щур Н. Мовний коучинг як технологія навчання англійської мови професійного спрямування у нелінгвістичних ЗВО. Вісник Київського начіонального лінгвістичного університету. Серія: Педагогіка та психологія. 2020. Вип 32. С. 143-150.

\section{REFERENCES}

1. Poberezska H.H. (2017). Kouchynh yak pedahohichna tekhnolohiia studentotsentrychnoho navchannia $\mathrm{u}$ VNZ [Coaching as a Pedagogical Technology of Student-centric Education in Higher Education]. Tekhnolohiia i tekhnika drukarstva. Vol. 4, no. 58. pp. 99-107.

2. Oliynyk I.V. (2019). Vykorystannia kouchynh-tekhnolohii u protsesi formuvannia doslidnytskoyi kompetentnosti u maybutnikh doktoriv filosofii v umovakh aspirantury [The Use of Coaching Technology in the Formation of Research Competence in Future Doctors of Philosophy in Graduate School]. Visnyk universytetu imeni Alfreda Nobelya. Pedahohichni nauky. Seriia «Pedahohika i psykholohiia». Vol. 17, no. 1. pp. 158-167.

3. Cywińska A., Majewska S., Pępiak-Kowalska K., Szwec E. (2013). Coaching. Wydanie pierwsze, Lublin, 190 p.

4. Rudnytskykh O.V. (2014). Kouchinh yak interaktyvna tekhnolohiia v osviti [Coaching as an interactive technology in education]. Visnyk Dnipropetrovskoho universytetu imeni Alfreda Nobelia. Seriia: Pedahohika i psykholohiia. No. 2. pp. 173-176.

5. Kaplinskyi V.V., Burlaka N.I., Fritsyuk V.A. (2020). Rol navchalnoi dystsypliny «Kouchynh v osviti» u pidhotovtsi mahistriv spetsialnosti 011 Osvitni, pedahohichni nauky [The Role of the Discipline «Coaching in Education» in the Training of Masters of the Specialty 011 Educational, Pedagogical Sciences]. Naukovi zapysky VDPU imeni Mykhayla Kotsiubynskoho. Seriia: Pedahohika i psykholohiia. Vol. 64. pp. 72-77.

6. Savchuk B., Bilavych H., Dushenko Yu. (2019). Kouchynh yak filosofiia i tekhnolohiia rozvytku profesiinoi pedahohichnoi osvity [Coaching as Philosophy and Technology of Development Professional Pedagogical Education]. Hirska shkola Ukrayinskykh Karpat. No. 21. pp. 82-87.

7. Horuk N. (2015). Kouchynh yak efektyvna tekhnolohiia formuvannia samoosvitnoi kompetentnosti studentiv [Coaching as an effective technology for the formation of self-educational competence of students]. Problemy pidhotovky suchasnoho vchytelia. No. 11. pp. 99-105.

8. Shevchuk S.P., Shevchuk O.S. (2016). Kouchynh yak metod navchannia studentivu konteksti reformuvannia vyshchoi osvity Ukrainy [Coaching as a method of teaching students in the context of reforming higher education in Ukraine]. Zb. nauk. prats Chornomor. derzh. un-tu im. P. Mohyly. Ser.: Pedahohika. Vol. 269, no. 257. pp. 62-65.

9. Nezhynska O.O., Tymenko V.M. (2017). Osnovy kouchynhu: navchalnii posibnyk [Fundamentals of coaching: a textbook], TOV «DISA PLYUS», Kyiv; Kharkiv, 220 p.

10. Kudryk L.H., Banakh O.V. (2020). Perevahy osvitnoho kouchynhu v konteksti pedahohiky partnerstva [Advantages of educational coaching in the context of partnership pedagogy]. In Eds.: O. Yu. Dykyi, H. A. Kolomoiets, A. A. Rebryna. Shlyakhy udoskonalennia profesiynykh kompetentnostei fakhivtsiv $v$ umovakh sohodennia: materialy Mizhnar. nauk.-prakt. internet konf. (Kyiv, 28-29 travnia 2020), pp. 58-61. 
11. Chernova T.Yu., Holiiad I.S., Tishchuk O.A. (2016). Pedahohichnyy kouchynh: navch.-metod. posib. [Pedagogical coaching]. Ed. D. E. Kilderova. Kyiv, 166 p.

12. Kudryk L., Beshley A., Melnyk U. (eds.). (2019). Samokouchynh: Yak zapobihty profesiinomu vyhoranniu [Self-coaching: How to prevent burnout], «Vydavnycha hrupa «Shkilnyi svit», Kyiv, 216 p.

13. Stoltzfus T. (2012). Sztuka zadawania pytań w coachingu. Wyd. Aetos Media, Wrocław, 102 p.

14. Nikolayev L., Romanenko N. (2020). Pidvyshchennia motyvatsii studentiv VNZ do navchalnoi diialnosti: kouchynhovyi pidkhid [Increasing the Motivation of University Students to Study: a Coaching Approach]. In Eds.: W. Duczmal, I. Ostopolets. Improving living standards: current opportunities and limitations: monograph, The Academy of Management and Administration in Opole, Opole, pp. 507-517.

15. Kuzan H. (2019). Osvitnii kouchynh yak innovatsiina tekhnolohiia profesiynoi pidhotovky fakhivtsiv sotsialnoi ta sotsialno-pedahohichnoi sfery u vyshchii shkoli [Educational Coaching as an Innovative Technology for Professional Training of Social and Socio-Pedagogical Specialists in Higher Education]. Molod i rynok. Vol. 3, no. 170. pp. 81-84.

16. Holiiad I.S., Chernova T.Yu. (2017). Rol kouchynhovoi kompetentnosti pedahoha u rozkrytti potentsialu subiekta osvitnoho protsesu [The Role of Coaching Competence of the Teacher in Revealing the Potential of the Subject of the Educational Process]. Naukovyi chasopys Natsionalnoho pedahohichnoho universytetu imeni M.P. Drahomanova. Seriia 13: Problemy trudovoi ta profesiynoi pidhotovky: zb. nauk. prats. Vol. 8. pp. 20-25.

17. Bilyk N.I., Lyubchenko N. V. (2020). Pedahohichnyi kouchynh yak tekhnolohiia profesiinoho rozvytku vchytelia v systemi pidvyshchennia kvalifikatsii [Pedagogical Coaching as a Technology of Professional Development of Teachers in the System of Advanced Training]. Imidzh suchasnoho pedahoha. Vol. 5, no. 194. pp. 41-46.

18. Khmelnytska S. (2017). Kouchynh yak suchasna tekhnolohiia pidvyshchennia efektyvnosti navchalnoho protsesu [Coaching as a modern technology to increase the efficiency of the educational process]. Molodyi vchenyi. Vol. 6. pp. 315-319.

19. Costa L.A., Garmston J.R. (2016). Cognitive coaching: developing self-directed leaders and learners. 3rd ed., Rowman and Littlefield Publishers, Lanham, MD, 408 p.

20. Semehyn T., Kucher V. (2021). Vykorystannia kouchynhu pid chas formuvannia inshomovnoi komunikatyvnoi kompetentnosti studentiv. [Coaching Usage in the Formation of Students' Foreign Language Communicative Competence]. Pedahohika formuvannia tvorchoi osobystosti u vyshchii $i$ zahalnoosvitnii shkolakh. Vol. 3, no. 75. pp. 57-60.

21. Zhovnir M.M. (2018). Kouchynh-tekhnolohii na zaniattiakh movnoho tsyklu: do pytannia vprovadzhennia i kontroliu navchalnykh dosiahnen studentiv [Coaching Technologies in Language Classes: on the Implementation and Control of Student Achievement]. Aktualni pytannia kontroliu yakosti osvity $u$ vyshchykh navchalnykh zakladakh: mater. naukovo-praktychnoyi konferentsiyi (Poltava, 22 bereznya 2018), pp. 91-93.

22. Shchur N. (2020). Movnyi kouchynh yak tekhnolohiia navchannia anhliyskoi movy profesiinoho spriamuvannia u nelinhvistychnykh ZVO [Language Coaching as a Technology of Teaching English for Professional Purposes in Non-linguistic Free Economic Zones]. Visnyk Kyivskoho natsionalnoho linhvistychnoho universytetu. Seriia: Pedahohika ta psykholohiia. Vol. 32. pp. 143-150. 